\title{
Foliar element distributions in Guadua bamboo, a major forest dominant in southwestern Amazonia
}

\author{
Received: 27 September 2021 / Accepted: 15 December 2021 \\ Published online: 17 February 2022 \\ (c) The Author(s) 2022 OPEN
}

Risto Kalliola ${ }^{1}$ - Ari Linna $^{1} \cdot$ Kalle Ruokolainen $^{2} \cdot$ Esa Tyystjärvi $^{3} \cdot$ Carl Lange $^{4}$

\begin{abstract}
Silica is the best-known component filling the spaces that form phytoliths in many plants, but phytoliths may also contain other elements. We used scanning electron microscopy with energy-dispersive X-ray spectroscopy (SEM-EDX) to map element distributions in the leaves of Guadua bamboo, which is a successful competitor in southwestern Amazonian forests. We emphasize immobile elements that can be mineralized (silicon and calcium) as well as potassium, an abundant mobile nutrient with many vital functions. We discovered high silicon (Si) content with little or no calcium (Ca) or potassium (K) in bulliform cells, bilobate shaped short cells and stomata, all of which can form phytoliths, and moderately high Si content in the bundle sheet, prickle tips and papillae. K often surrounded Si-loaded cells, Si and K had overlapping distributions in the intercostal areas near vein margins, and Ca showed abundant spotted distribution in the intercostal areas. The dark inside content of the costal zones of some samples in light microscopy showed no mineralization but prominently contained sulfur. Adjacent fusoid cells showed different $\mathrm{Si}$, $\mathrm{K}$ and $\mathrm{Ca}$ combinations, which may suggest potentially variable functions of these cells. Widespread Si deposition strengthens Guadua bamboo leaves and may help it to outcompete tree species during periods of drought.
\end{abstract}

Keywords Bulliform cell · Calcium · Element map · Fusoid cell · Phytolith · Potassium · Silica

\section{Introduction}

Plants absorb mineral nutrients from groundwater and transport them into their vegetative structures. Some plant groups deposit intracellular or extracellular mineral accretions with characteristic forms but unclear functions. In many plants, silicon (Si) forms microscopic grains called phytoliths [1] but as a plant nutrient, $\mathrm{Si}$ is essential only in Equisetaceae [2]. Several plants contain aquaporins that are specialized as Si transporters [3, 4], revealing that silicon is important in plants although its effects are often indirect [5-7]. Silicon may act as a metabolically cheap substitute for cellulose to add strength to plant structure [8] and hence prevent wilting under water stress, or improve plant resistance to herbivores or pathogens $[9,10]$.

Elements other than silicon may also mineralize either together with $\mathrm{Si}$ in silicophytoliths or as the main component of a phytolith. For example, focusing on metals, woody plant phytoliths frequently contain aluminum (AI) in the form of aluminosilicates, but Al was absent from herbaceous phytoliths [11]. Silica phytoliths isolated from barley [12] contained Al, scandium (Sc), titanium (Ti), vana$\operatorname{dium}(\mathrm{V})$, cesium $(\mathrm{Cs})$, iron (Fe) or rare-earth elements but not the major nutrients or other inorganic constituents of plants like potassium (K), calcium (Ca), magnesium (Mg),

$\triangle$ Risto Kalliola, risto.kalliola@utu.fi| ${ }^{1}$ Department of Geography and Geology, University of Turku, 20014 Turku, Finland. ${ }^{2}$ Department of Biology, University of Turku, 20014 Turku, Finland. ${ }^{3}$ Department of Life Technologies, University of Turku, 20014 Turku, Finland. ${ }^{4}$ Top Analytica Ltd, Ruukinkatu 4, 20540 Turku, Finland. 
manganese $(\mathrm{Mn})$, chlorine $(\mathrm{Cl})$ and bromine $(\mathrm{Br})$. The element compositions of phytoliths may also vary between plant taxa or in response to soil substrate or climate, yet the method used for extracting phytoliths from plant material may also affect the observed chemical composition [13]. In addition to inorganic constituents, silicophytoliths can include occluded carbon that may remain in the soil for very long times and thereby contribute to carbon bio-sequestration from the atmosphere $[14,15]$. This hypothesis is criticized, however, because at least part of phytolith-occluded carbon in living plants originates from the soil and can therefore produce misleadingly old datings [16]. In archaeology, phytoliths can give information about ancient vegetation and domesticated plants [17].

Calcium also sometimes mineralizes in plant tissues, yet Ca as an essential plant nutrient is required for a number of specific structural and functional roles in every cell. Solid calcium oxalate $(\mathrm{CaOx})$ and calcium carbonate $\left(\mathrm{CaCO}_{3}\right)$ deposits can be common within live mesophyll cells. As $\mathrm{Ca}^{2+}$ is a relatively immobile plant nutrient [18], calcium oxalate crystals could act as Ca storage [19]. Large biomineralizations of $\mathrm{Ca}$ oxalates, phosphates or carbonates are called calcium phytoliths or cystoliths [20]. Bulky, globular or elongated cystoliths have also been shown to affect light scattering inside Ficus leaves, thereby improving illumination deep in the leaf [21], and thereby enhancing photosynthesis.

In contrast to the immobile elements discussed above, potassium is a mobile element in plant physiology. The $\mathrm{K}^{+}$ ion is the most abundant inorganic cation in plant cells, contributing up to $10 \%$ of the total dry matter of plants. It has many essential roles in plant cells, including contributions to osmotic pressure regulation, enzyme activation and photosynthesis [22]. Potassium influences foliar $\mathrm{CO}_{2}$ uptake and transpiration by regulating the opening and closing of stomata. The $\mathrm{K}^{+}$cation is stored inside vacuoles, and as a soluble ion it easily moves in a plant. Potassium is not, however, a constituent of the structurally important molecules of plant organic matter [22, 23].

We apply in this study scanning electron microscopy with energy-dispersive X-ray spectroscopy (SEM-EDX) for detailed mapping of silica and calcium as immobile elements that can form mineralizations, as well as potassium as a mobile nutrient without such a trait. Although SEM-EDX is most widely used in materials science, it also has many biological applications. For example, it has been used to map the localizations of cadmium (Cd) in the leaves of Lemna polyrhiza [24] and Si in the leaf blades of two Asian bamboos $[25,26]$.

Bamboos together with other members of the Poaceae family are intriguing for detailed element mapping because they commonly form silicophytoliths in bulliform cells, long and short cells and hair cells $[27,28]$. The other anatomical positions of bamboo foliar phytoliths, though fewer, include the mesophyll, tracheid and vascular tissues [27]. Some mineralization may also occur in fusoid cells $[29,30]$. It is not clear, however, whether silica deposition in particular cells is a passive result of water uptake or an active process [25].

We apply SEM-EDX mapping in field samples of the bamboo species Guadua sarcocarpa Londoño and Peterson. It is a giant (up to $15 \mathrm{~m}$ tall) and competitive bamboo species that dominates, together with its sister species $G$. weberbaueri Pilg., over $160,000 \mathrm{~km}^{2}$ of lowland rainforest in southwestern Amazonia [31, 32]. Reasons for the bamboos dominance in these areas are not well known but future success nevertheless requires a good ability to withstand the effects of global warming, such as extreme dry seasons. If Guadua bamboos were to decline, vast tropical forests could change to open grasslands [33].

\section{Material and methods}

We collected leaf samples of Guadua bamboo from eleven different Western Amazonian locations during 2017 and 2018 and used them in a light microscopy study [30]. The present study contains a subset of the most intriguing microscopy slides originating from two different localities in Southern Peruvian Amazonia: three samples (collection numbers 10,16 and 20$)$ from Primavera $\left(11.04^{\circ} \mathrm{S}\right.$, $\left.69.57^{\circ} \mathrm{W}\right)$ and one from San Carlos $\left(10.75^{\circ} \mathrm{S}, 73.64^{\circ} \mathrm{W}\right)$. Both localities belong to a bamboo population that covers ca. $2,500 \mathrm{~km}^{2}$ and flowered in 2018 , soon after our field trip (Van doninck et al. 2020). The population forms a bit more than $1 \%$ of a large area of Guadua bamboo-dominated evergreen to semi-deciduous forest in the borderlands of Peru, Brazil and Bolivia [31, 32]. Each sample was a part of a leaf blade, which we put in a small paper bag within a plastic container with silica gel to achieve rapid drying.

We applied the dry ashing method for sample preparation [30]. Each sample consisted of about a $1 \mathrm{~cm}$ long part of a leaf blade, which we first embedded on microscopy glass in Tissue-Tek compound and then heated in a laboratory furnace by stepwise $\left(5^{\circ} \mathrm{C} / \mathrm{min}\right)$ increase of the temperature to $600^{\circ} \mathrm{C}$ to ensure their complete burning. Samples were burned both without a cover glass, resulting in a degree of sample folding, and between two microscopy glasses but with possible problems caused by cover glass heating. We also prepared transverse sections by embedding the leaf sample (Primavera-10) into Struers EpoFix. After hardening, the sample was cut, leveled and polished down to $30 \mu \mathrm{m}$. Light microscope studies were made at $100 \times$ and $250 \times$ magnifications in order to distinguish different areas of mineralization (Fig. 1). For classification, we 
Fig. 1 Light microscope photographs of Guadua bamboo leaf after dry ashing. a Adaxial (upper) leaf surface (Primavera-2); b Mesophyll (Primavera-16). Abbreviations: $i=$ intercostal zone, $c=$ costal zone (leaf vein), $c d=$ costal zone with dark inside content, $b=$ bulliform cell, $b i=$ bilobate short cell, sa $=$ saddle shaped short cell, $f=$ fusoid cell with presumed mineralization, $\mathrm{ft}=$ translucent fusoid cell a

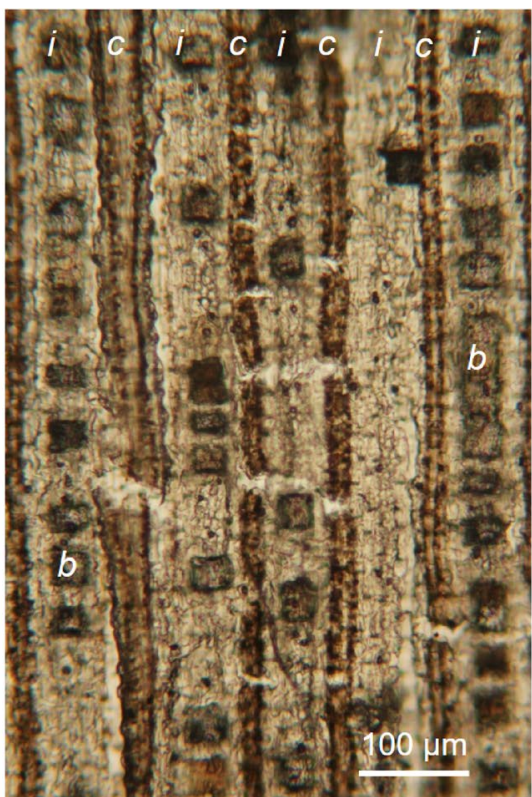

b

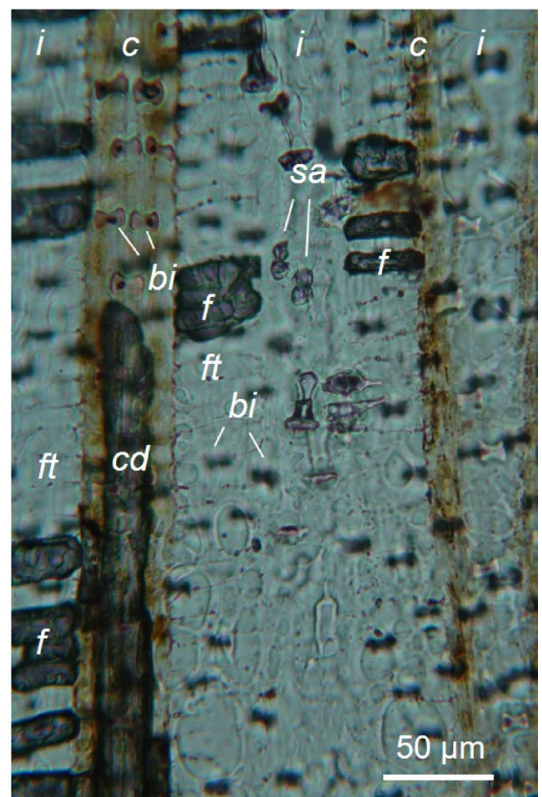

consulted the International Code for Phytolith Nomenclature [34].

We selected 15 samples of interest to study by scanning electron microscopy with energy-dispersive $X$-ray spectroscopy (SEM-EDX). In folded samples (see above) we undertook progressive sample leveling (each time $10 \mu \mathrm{m}$ deeper) to expose structures of particular interest. We used a field emission scanning electron microscope (SEM) (Zeiss, GeminiSEM 450, Oberkochen, Germany 2018) and applied EDS mapping by energy dispersive spectroscopy (EDS) (Bruker XFLash 5060F and XFlash 6|60, Nano GmBH, Berlin, Germany 2018). The samples were coated with carbon (Agar Scientific Ltd, UK, model: B7367A) and fixed on an aluminum sample holder with copper and carbon adhesives to ensure electrical contact between sample and ground. High vacuum conditions $\left(p<1.0 \cdot 10^{-6} \mathrm{~Pa}\right)$ were applied in all images and electronic spectra. The instrument manufacturer's ESPRIT v.2.1.2.17832 software was used for coloring and enhancing the contrast of the elements of interest, while the GNU Image Manipulation Program (GIMP) v. 2.10.12 was applied for constructing the montage images. Heat maps of element contents were prepared for showing in relative scale the distributions of the detected counts per second per electron volt (cps/eV). In those maps, relative element densities are imagined by colors from very low (dark blue) to very high (bright red). We also prepared line charts to reveal EDS spectra and element intensities (contents) in selected areas or transects of interest.

\section{Results}

The light microscopy view of the adaxial leaf surface displays costal zones of different widths, and the intercostal areas with discontinuing chains of conspicuous bulliform cells (Fig. 1a). When the microscope focuses leaf mesophyll, tight rows of fusoid cells (dark or translucent) and widely dispersed short cells (bilobate, saddle-shaped) appear (Fig. 1b). Figure 1b also displays an occasional case where the costal zone contains dark infilling. The EDS maps showed no signal of $\mathrm{Si}, \mathrm{K}$ or $\mathrm{Ca}$ (not shown) for these structures, while their sulfur (S) content was elevated (Fig. 2c-f).

Bulliform cells can be silicified or have no silica (Fig. 3). They contain little or no potassium, yet $\mathrm{K}$ can show up in cells with reduced $\mathrm{Si}$ (Fig. 4). Potassium commonly forms a layer around bulliform cells (Figs. 2d, 5e, 6e). Si and K also have some overlapping high-content areas in the leaf parenchyma in some areas near vein margins (Figs. 2c, d, $5 d, e, 6 d, e)$. Vein margins can alternatively show high levels of calcium, yet Ca mainly appears with high-content spots dispersed widely around the leaf parenchyma (Figs. 5f, 6f).

Fusoid cells form stacks, attached nearly perpendicularly to the costal zones, and show variable element contents (Fig. 6). Out of the cells with a dark appearance in light microscopy, some contain $\mathrm{Si}, \mathrm{K}$ and $\mathrm{Ca}$ (yellow arrows in Fig. 6) while others have high Ca but contain hardly any $\mathrm{K}$ and $\mathrm{Si}$ (red arrows). The translucent cells in light microscopy can either contain Ca with low K (pink arrow) or not show any of the three elements (white arrow). In a pair of opposite fusoid cells attached to the same vascular bundle (Fig. 7), both display weakly elevated Si, but only the 
Fig. 2 Costal zone (vein) with dark inside content, also one bulliform cell (Primavera-16). a Light microscope picture with the dotted line demarcating margins of areas lost during sample leveling before SEM b SEM image with demarcated location of the EDS transect; c-e EDS maps Si, K and $S$, respectively; $\mathbf{f}$ Intensity of $S$ along the EDS transect (below, magnification of the SEM corresponding to the EDS transect). Abbreviations: $i=$ intercostal zone, $c=$ costal zone, $c d=$ costal zone with dark inside content, $b=$ bulliform cell a

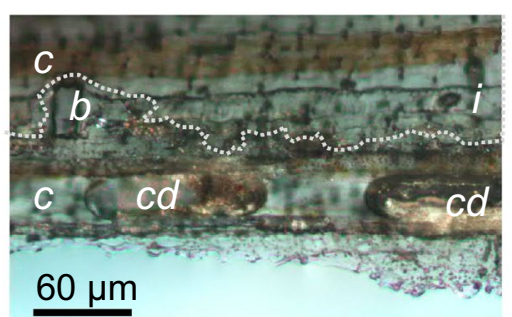

C

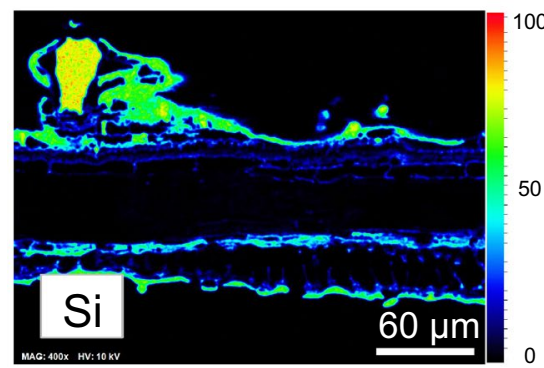

e

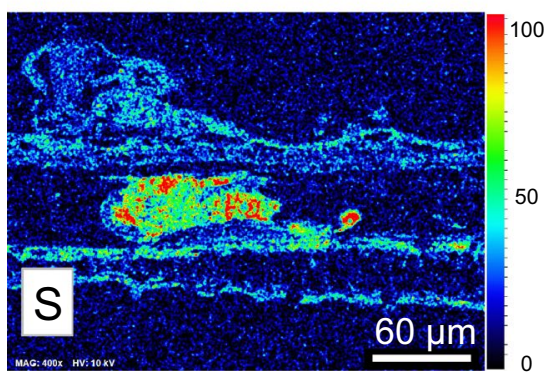

a

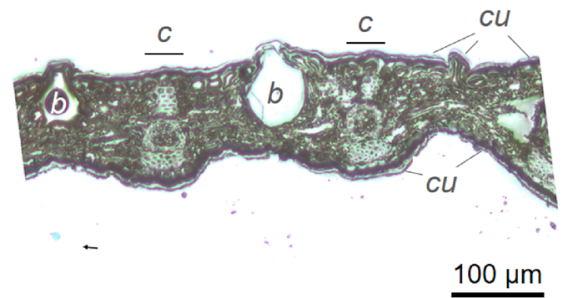

C

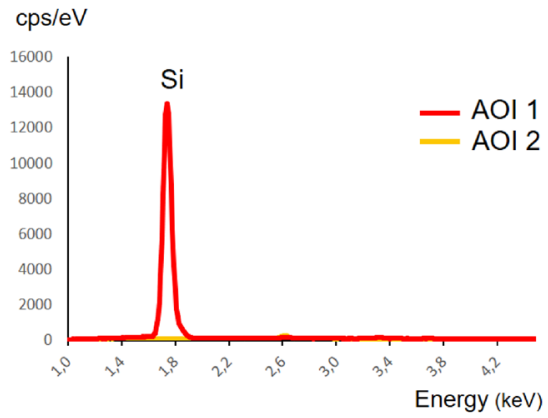

b

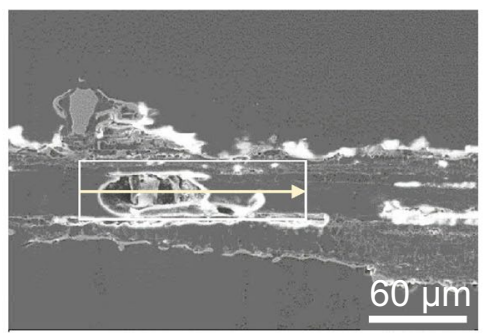

d
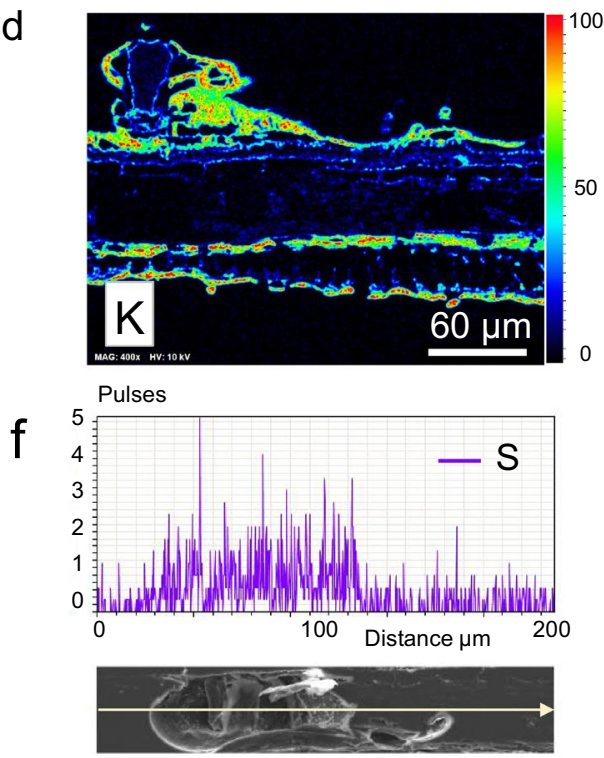

b
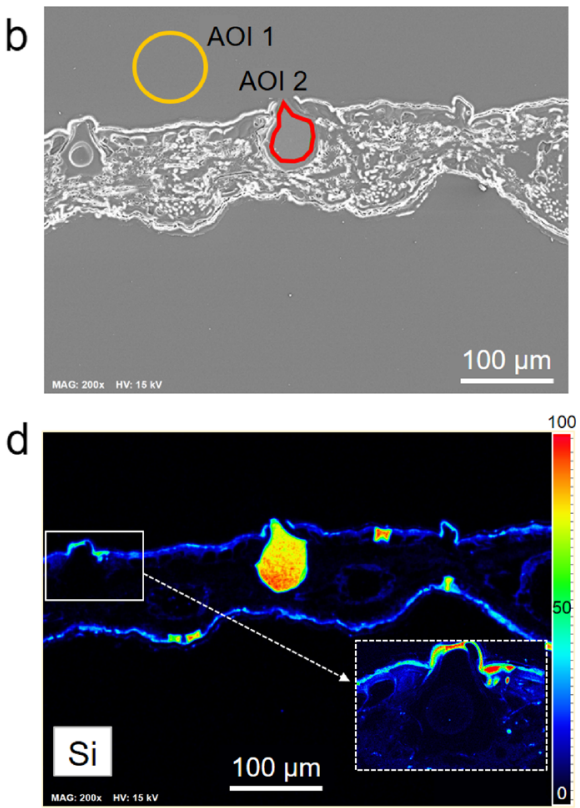

one with the dark appearance in light microscopy (Fig. 7a) also reveal elevated $\mathrm{S}$ and $\mathrm{Ca}$. The emptier-looking cell, instead, shows a peak of $\mathrm{Cl}$ (Fig. 7c). Other areas with raised
Si content in this foliar transverse section include the cuticle and cell walls and/or the extracellular areas in both the epidermis and bundle sheet (Fig. 7d). The most prominent 
Fig. 4 Intercostal row of densely packed bulliform cells (Primavera-20). a SEM image with four demarcated AOls (AOI 3 showing the background); $\mathbf{b}$ EDS spectra in the AOls with the most prominent peaks labeled for the minerals they represent; c EDS map of $\mathrm{Si} ; \mathbf{d}$ EDS map of $\mathrm{K}$ a

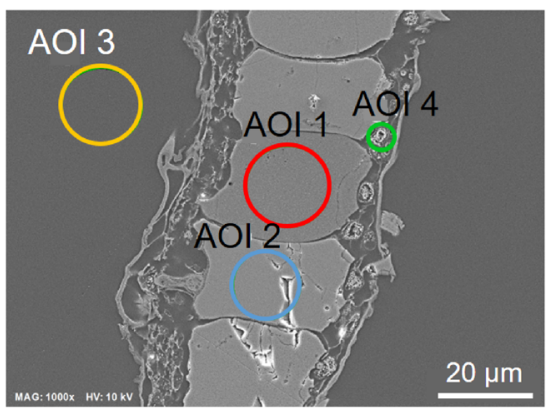

C

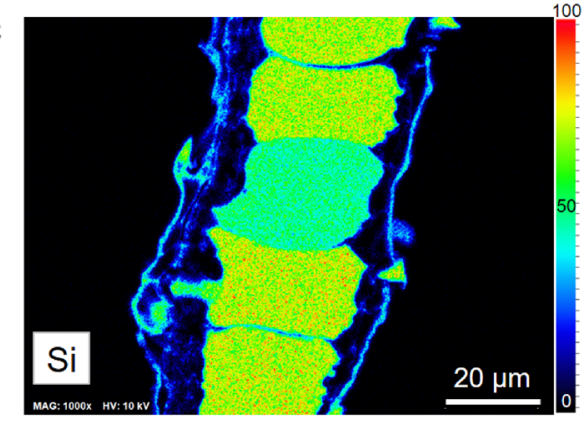

b cps/ev

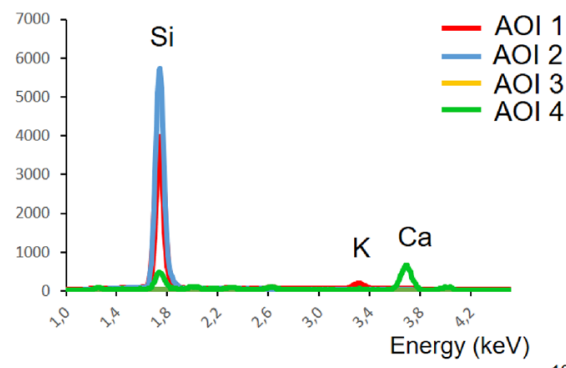

d

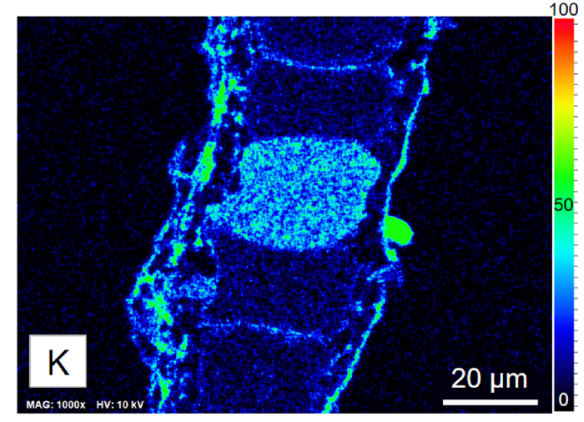

Fig. 5 Two costal and intercostal zones (Primavera-16). a Light microscope picture with the dotted line demarcating margins of areas lost during sample leveling before SEM; $\mathbf{b}$ SEM image with demarcated location of the EDS transect crossing a bulliform cell; c Intensities of $\mathrm{Si}, \mathrm{K}$ and $\mathrm{Ca}$ along the EDS transect (below, magnification of the SEM corresponding to the EDS transect); d-f EDS maps of Si, $\mathrm{K}$ and $\mathrm{Ca}$, respectively. Abbreviations: $b=$ bulliform cell, $c=$ costal zone a

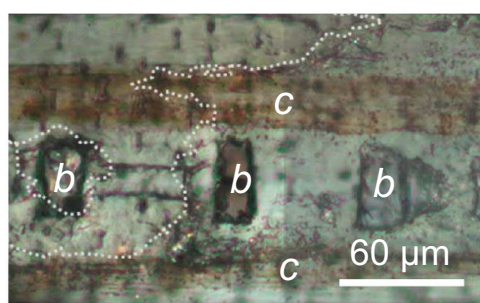

C

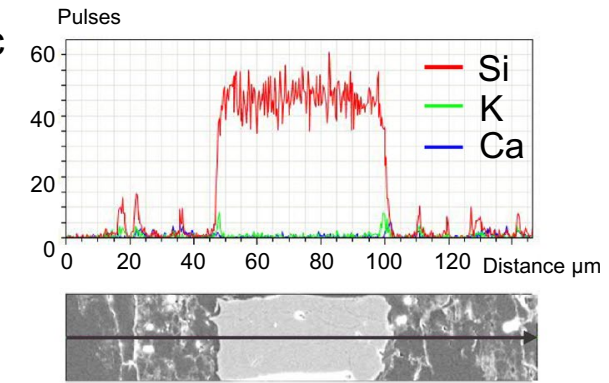

e

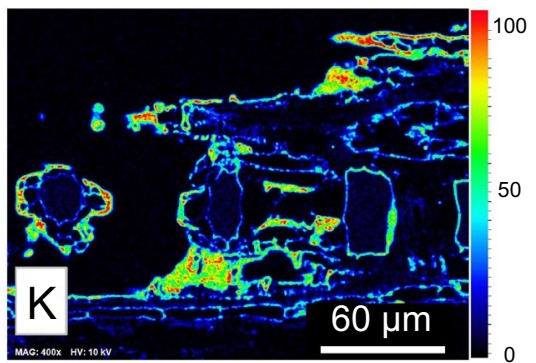

b

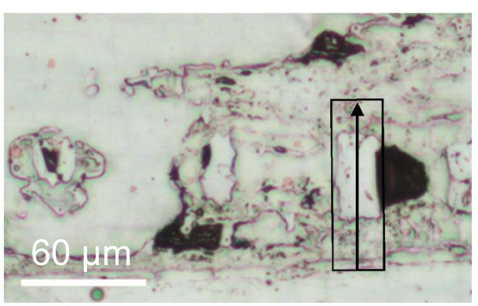

d

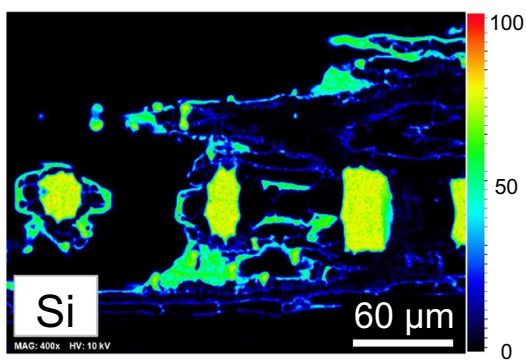

f

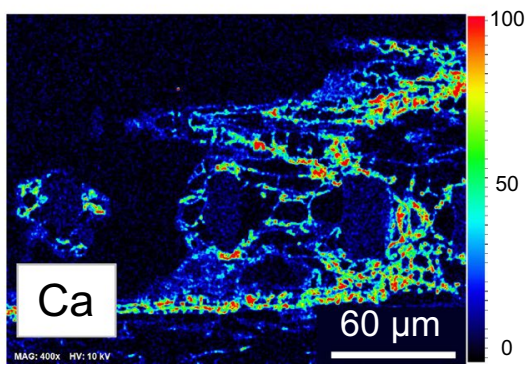

Si contents of this sample, however, occur in the stomata of the abaxial epidermis.
In top view, the abaxial epidermis shows elongated cells with ample stomata in the intercostal zone and elongated cells with perpendicularly arranged bilobate cells in the 
Fig. 6 Fusoid cells attached to costal zones with three bulliform cells in the intercostal zone (San Carlos-10). a Light microscope picture; $\mathbf{b}$ SEM image with demarcated location of the EDS transect across a row of fusoid cells; $c$ Intensities of $\mathrm{Si}, \mathrm{K}$ and $\mathrm{Ca}$ along the EDS transect (below, magnification of the SEM corresponding to the EDS transect); d-f EDS maps of Si, $\mathrm{K}$ and $\mathrm{Ca}$, respectively. Abbreviations: $b=$ bulliform cell, $c=$ costal zone, $f=$ fusoid cell with dark content, $f t=$ fusoid cell (translucent). Arrows (pink, yellow, white, red) help to compare element contents in individual fusoid cells

Fig. 7 Foliar transverse section of a vascular bundle with two fusoid cells (Primavera-10). a Light microscope picture; $\mathbf{b}$ SEM image with three defined AOls (AOI 1 showing the background); $c$ EDS spectra of the demarcated AOIs; $\mathbf{d}$ EDS map of Si. Abbreviations: $x=$ xylem, $p=$ phloem,$b s=$ bundle sheet, $f=$ fusoid cell, $p a=$ parenchyma, $e=$ epidermis, $c u=$ cuticle, st = stomata a

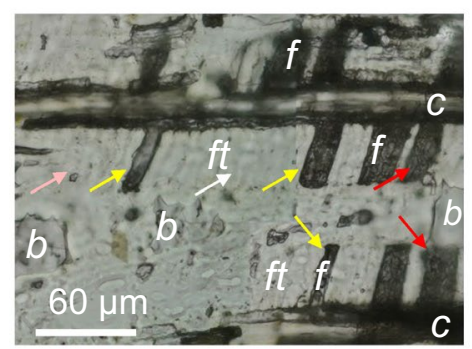

C

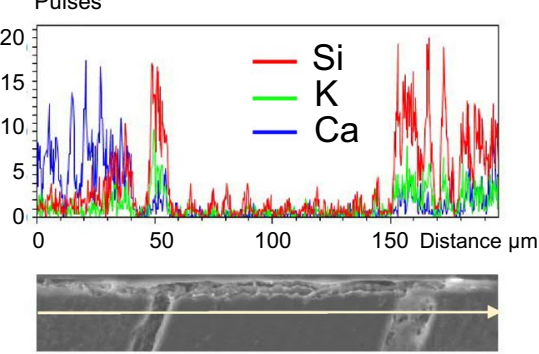

e

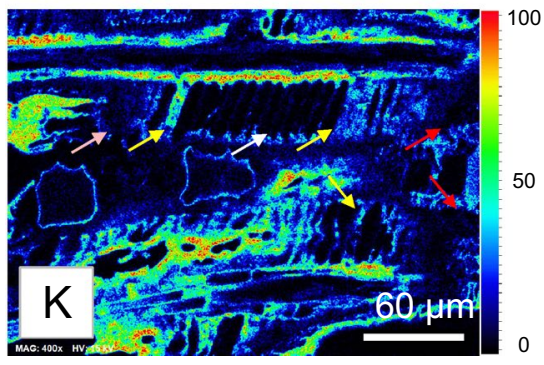

a

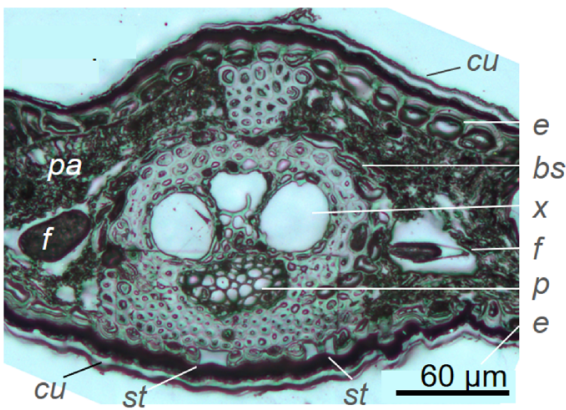

C

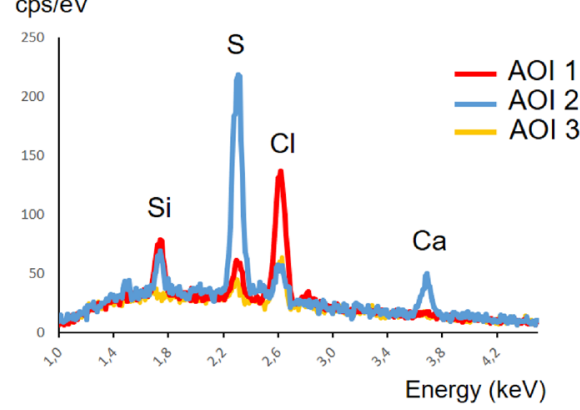

b

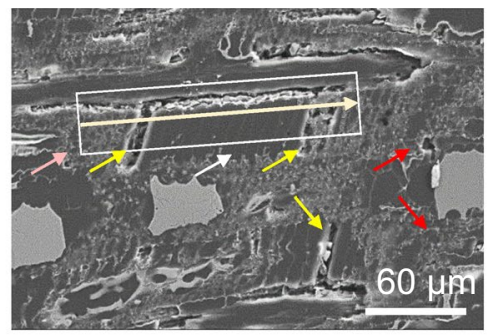

d

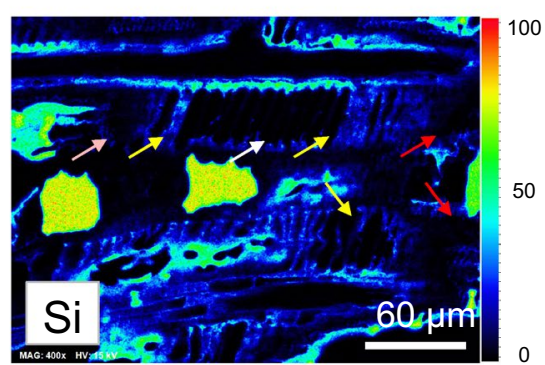

f

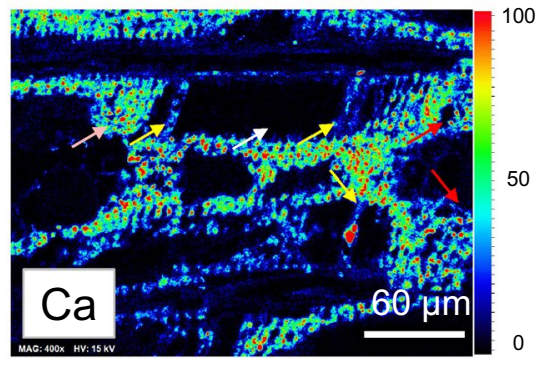

b

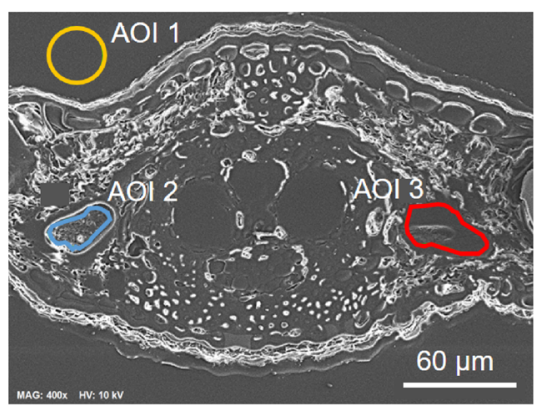

d

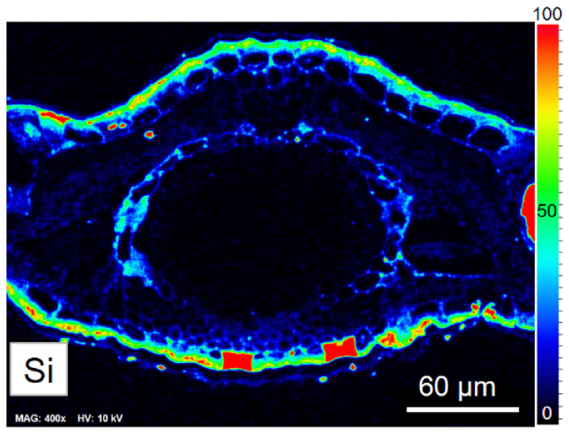


Fig. 8 Structure of the abaxial leaf-blade of Guadua bamboo (Primavera-20). a SEM image with two defined AOIs; $\mathbf{b}$ EDS spectra in the AOls with the most prominent peaks labeled for the minerals they represent c-d EDS maps Si and K, respectively. Abbreviations: $c=$ costal zone (indicated by orange dot line in the left), $i=$ intercostal zone (indicated by yellow), $s t=$ stomata,$p r=$ prickle, $p a=$ papillae, $s t=$ stoma, $b i=$ bilobate short cell a

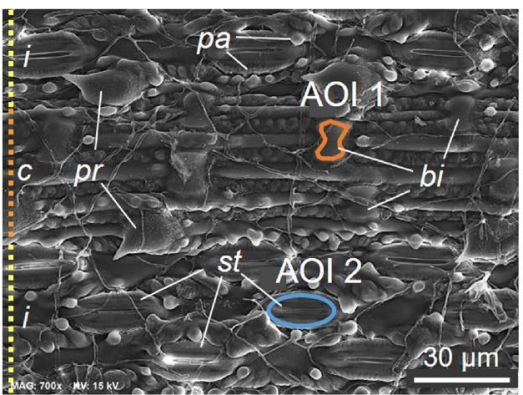

C

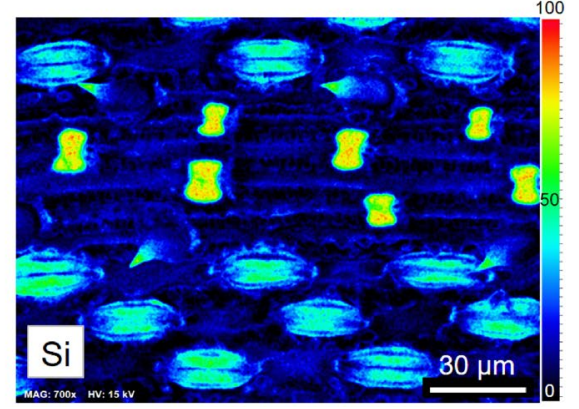

b

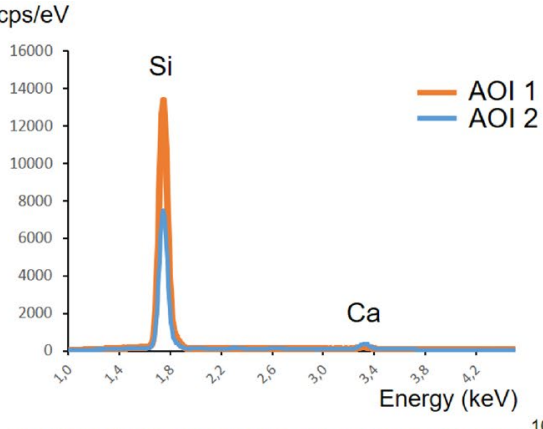

d

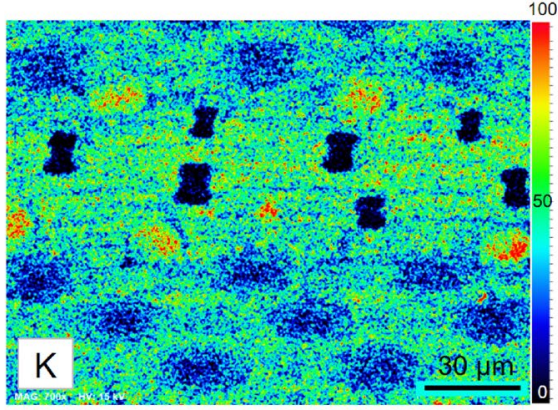

costal zone (Fig. 8). The entire epidermis contains plentiful papillae, both solitary and rows, and prickles near the margin between costal and intercostal areas. The EDS map reveals somewhat elevated $\mathrm{Si}$ in the papillae, a bit higher $\mathrm{Si}$ in the stomata and prickle tips, and the highest contents in the bilobate cells. K has almost the opposite distribution, as it is high in the costal long cells, even higher in the prickle bases, and low to very low in the areas where $\mathrm{Si}$ abounds. Focusing on the bilobate cells with major detail (Fig. 9), both their surface and interior are rich in $\mathrm{Si}$ with the exception of the dark spot inside. $\mathrm{K}$ shows somewhat elevated levels in the surface of the bilobate cells. Figure 9e shows bilobate cells to have no carbon (C) except in the dark dot where its levels are, however, comparable with those of the background.

\section{Discussion}

The elements analyzed in the present study have different physiological roles. Silicon is a poorly understood plant constituent, and neither its role in plant metabolism nor its transport within the plant is known $[2,5] . \mathrm{K}^{+}$and $\mathrm{Cl}^{-}$ions participate in the osmotic regulation of the flow of water between plant cells [22]; $\mathrm{Ca}^{2+}$ is a common secondary messenger but also plays multiple other roles in both cell wall and cell division [35]; $\mathrm{S}^{2+}$ ions, in turn, occur in methionine and cysteine and in iron-sulfur centers. Virtually all metal nutrients also act as enzyme activators in plants. $\mathrm{K}^{+}$and $\mathrm{Cl}^{-}$move through cell membranes via channel proteins, whereas $\mathrm{Ca}^{2+}$ is actively pumped outside of the cytoplasm and moves in via channels. $\mathrm{K}^{+}$remains soluble in cytoplasm [22]. Sulfur is obtained as sulfate ions by specific transporters, activated to adenosine-5'-phosphosulfate, reduced to sulfide, and bound to cysteine [36]. $\mathrm{K}^{+}$moves in both xylem and phloem [22], whereas $\mathrm{Ca}^{2+}$ is transported only in the xylem [35] and therefore does not move downwards in a plant.

SEM-EDX maps showed many specific element distributions, reflecting the physiological roles, transport pathways and storage structures in different cell types of Guadua bamboo. For example, calcium, a constituent of cell walls (i.e., apoplast) and vacuoles [37], showed widespread spotted distribution in the intercostal areas, but was virtually absent from the silicon-accumulating cells and the costal zone (Figs. 4, 5). We found no clear indication of Ca cystoliths in Guadua bamboo. Sulfur was found in the occasional dark inside content of costal zones (Figs. 1b, 2e) and in some fusoid cells (Fig. 7c). The dark spot in bilobate cells showed no particular element signal (Fig. 9c, f), such as phytolith-occluded carbon that might have been expected based on earlier studies [38, 39]. This lack of signal should be interpreted with care, however, as the dry ashing method may have influenced the distributions of non-mineralizing elements like $S$ and $C$.

We found high silica contents in bulliform cells, bilobate and saddle-shaped short cells, and stomata (Figs. 1, $2,3,4,5,6)$, thereby agreeing with earlier studies $[25,27$, 28]. Silica is moderately high in the bundle sheet (Fig. 7d), prickle tips (Fig. 8c), and, often together with potassium, some mesophyll areas near vein margins (Figs. 5, 6, 7). These may be visualizations of orthosilicic acid $\mathrm{Si}(\mathrm{OH})_{4}$ and $\mathrm{K}^{+}$ions from xylem sap to other parts of bamboo leaves $[22,40-42]$. 
Fig. 9 Structure and composition of the bilobate short cells of Guadua bamboo (San Carlos 10). a Light microscope picture; b SEM image with demarcated location of the EDS transect; c-e EDS maps for Si, $\mathrm{K}$ and $\mathrm{C}$, respectively; $\mathbf{f}$ Intensities of $\mathrm{Si}$, $\mathrm{K}$ and $\mathrm{C}$ along the EDS transect (below, magnification of the SEM corresponding to the EDS transect). Abbreviations: $b i=$ bilobate cell, $d d=$ dark dot of the bilobate cell a

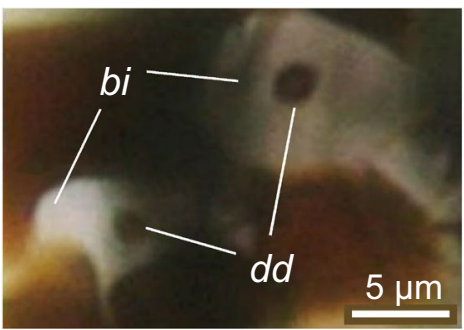

C

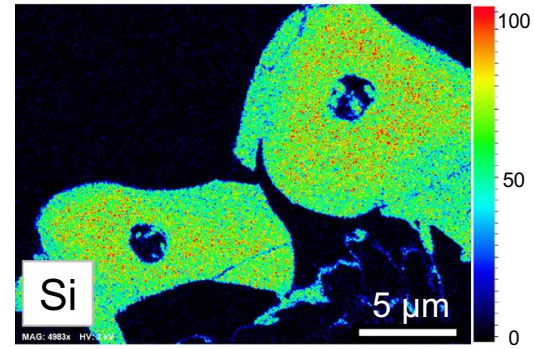

e

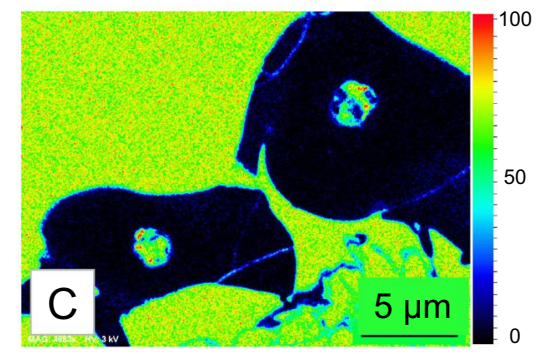

b

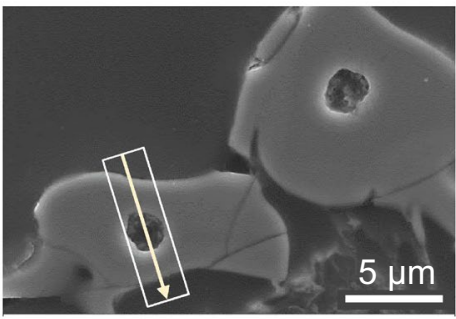

d

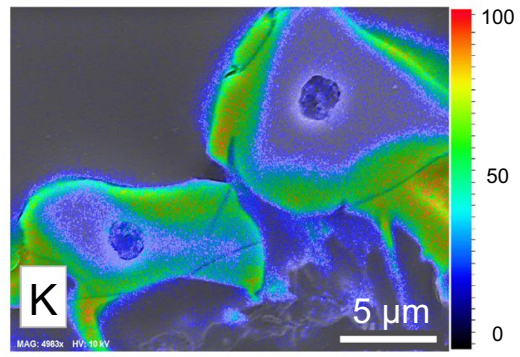

Pulses

f 100

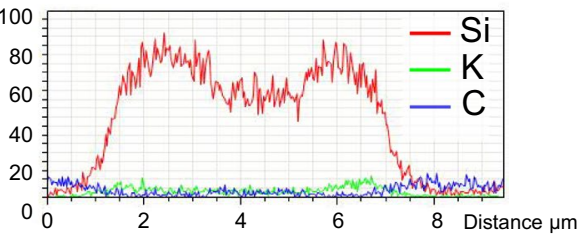

The known physiological activity of some silica accumulating cells can be incompatible with mineralization. It suggests that mineralization - especially the filling of the cell with amorphous silica - occurs when the cell has fulfilled a more dynamic function. This feature is particularly obvious in bulliform cells, which can shrink and enlarge in response to water availability only if they are not filled with amorphous Si [43]. Silicification reduces potassium (Figs. 2, $4,5,6)$ and in this way impedes cells from controlling their osmotic potential. In a histological analysis of a leaf-rolling mutant of rice, shrinkage of bulliform cells resulted in inward-curved leaves [44]. Silicification of guard cells (Fig. 8) possibly reduces stomatal movements.

Cell passivation through mineralization may also be an adaptive trait. Si-packed bulliform cells help bamboo keep its leaves unrolled during seasonal drought with conceivably positive impacts on plant vitality [25]. Si deposition in the structurally positioned bilobate cells (Figs. 1, 8, 9), bundle sheet (Fig. 7) and epidermis (Figs. 3d, 7d, 8c) can likewise contribute to the of the leaf blades' overall mechanical strength. Among other conceivable functions of $\mathrm{Si}$ in plant leaves (see examples in Introduction), the thick layer of epidermal silica with dense papillae (Figs. 3d, $7 d, 8 c)$ acts as a shield against pathogen penetration [16].

The rows of regularly arranged fusoid cells were intriguing in our data. These oblong structures can be living cells or cell-like gas spaces delimited by successive collapsed fusoid cells and their derivatives [29]. We propose that the cells appearing dark in light microscopy (Fig. 1b) may still be living. They always contain $\mathrm{Ca}$, and show only moderate to low levels, if any, of $\mathrm{K}$ and Si (Fig. 5). The translucent fusoid cells, in turn, are assumed to be cavities that can be enriched with $\mathrm{Ca}$ when it is abundant also in the sap of the adjoining costal zone (Fig. 5f). SEM-EDS maps also reveal local peaks of $\mathrm{Si}, \mathrm{K}$ and $\mathrm{Ca}$ near to the distal ends of the fusoid cell rows. In a leaf transverse section (Fig. 6), one longitudinally cut fusoid cell contained elevated $\mathrm{Ca}$ and $\mathrm{S}$, while another cell showed a peak of $\mathrm{Cl}$. The difference could result from cutting the two cells through different parts of their structure, yet nearby fusoid cells can indeed have contrasting element characteristics, as discussed above. Leandro et al. [29] have reviewed several possible functions for fusoid cells in grasses, related to cell structure, light scattering and photorespiration. The ontogeny of fusoid cells in two Guadua species suggests their possible role in apoplastic transport [45]. By showing contrasting $\mathrm{Si}, \mathrm{K}$ and $\mathrm{Ca}$ compositions between adjacent fusoid cells, our results suggest that individual fusoid cells may perform different functions.

The vast lowland plains with Guadua bamboo dominance in the southwestern Amazonian forests exhibit 
distinctive dry-season greening during the months when plants compete for water resources. According to remotely sensed water-content metrics, bamboo had lower water content index values than trees for most of the year, except for the early dry season, when the water content in bamboo foliage strongly increased [46]. Silicophytoliths help Guadua bamboo to keep its leaves stout and undamaged despite fluctuating water content, and thereby help it to outcompete tree species that cannot withstand seasonal water stress as well as Guadua bamboo. This hypothesis could be addressed by later empirical research.

\section{Conclusions}

The results agree with earlier studies by showing strong silica deposition in bulliform cells, short cells and stomata, and moderately high deposition in bundle sheet, prickle tips and papillae. Calcium displayed spotty wide distribution around leaf parenchyma. Potassium peaked around silicified cells, often overlapping with silica near leaf veins. Adjacent fusoid cells can have contrasting element combinations. The findings reveal functional details, like living cells with dissolved potassium getting inactivated by filling with amorphous silica. Changing cell characteristics may support Guadua survival by preventing leaf blade rolling or folding during periods of seasonal drought, thereby helping Guadua bamboo to outcompete tree species in the increasingly dry seasonal climate of southwestern Amazonia.

Acknowledgements We thank Natalia Reátequi for cooperation in the field, Arto Peltola for preparing the foliar transverse thin sections, Linnea Toiviainen and liro Seppä for their help in the laboratory and Top Analytica Itd (Turku, Finland) for SEM imaging, EDS mapping and montage images, and the Academy of Finland projects 296406 (RK) and 333421 (ET) for funding.

Author contribution The study was designed by RK and AL who together with KR collected the samples in the field. Laboratory work was done by $\mathrm{AL}$ (sample processing) and $\mathrm{CL}$ (SEM-EDX). All authors made data interpretation and participated in manuscript writing. ET provided plant physiological insight. All authors approved the final submission.

Main conclusion Leaves of Guadua bamboo accumulate Si in specialized cells and extracellular areas. Distributions of Si and K are interconnected. Fusoid cells show variable assemblages of $\mathrm{Si}, \mathrm{K}$ and $\mathrm{Ca}$.

Data availability The data used in this ms. consists of SEM-EDX imagery. In addition to the imagery included in this submission, some more element maps can be requested from the authors. Also light microscopy pictures can be requested.

\section{Declarations}

Conflict of interest We have no conflict of interest with anyone.
Open Access This article is licensed under a Creative Commons Attribution 4.0 International License, which permits use, sharing, adaptation, distribution and reproduction in any medium or format, as long as you give appropriate credit to the original author(s) and the source, provide a link to the Creative Commons licence, and indicate if changes were made. The images or other third party material in this article are included in the article's Creative Commons licence, unless indicated otherwise in a credit line to the material. If material is not included in the article's Creative Commons licence and your intended use is not permitted by statutory regulation or exceeds the permitted use, you will need to obtain permission directly from the copyright holder. To view a copy of this licence, visit http://creativecommons. org/licenses/by/4.0\%.

\section{References}

1. Sharma R, Kumar V, Kumar R (2019) Distribution of phytoliths in plants: a review. Geol Ecol Landsc 3(2):123-148. https://doi.org/ 10.1080/24749508.2018.1522838

2. Epstein $E$ (1994) The anomaly of silicon in plant biology. Proc Natl Acad Sci 91:11-17. https://doi.org/10.1073/pnas.91.1.11

3. Ma JF, Tamai K, Yamaji N, Mitani N, Konishi S, Katsuhara M, Ishiguro M, Murata Y, Yano M (2006) A silicon transporter in rice. Nature 440:688-691. https://doi.org/10.1038/nature04590

4. Katz O, Puppe D, Kaczorek D, Prakash NG, Schaller J (2021) Silicon in the soil-plant continuum: intricate feedback mechanisms with ecosystems. Plants 10:652. https://doi.org/10.3390/plant s10040652

5. Shi Y, Wang Y, Flowers TJ, Gong H (2013) Silicon decreases chloride transport in rice (Oryza sativa L.) in saline conditions. J Plant Physiol 170:847-853. https://doi.org/10.1016/j.jplph.2013.01. 018

6. Flam-Shepherd R, Huynh WQ, Coscun D, Hamam AM, Britto DT, Kronzucker HJ (2018) Membrane fluxes, bypass flows, and sodium stress in rice: the influence of silicon. J Exp Bot 69(7):1679-1692. https://doi.org/10.1093/jxb/erx460

7. Yan G, Fan X, Tan L, Yin C, Li T, Liang Y (2021) Root silicon deposition and its resultant reduction of sodium bypass flow is modulated by OsLs1 and OsLs2. Plant Physiol Biochem 158:219-227. https://doi.org/10.1016/j.plaphy.2020.11.015

8. Biru FN, Cazzonelli Cl, Elbaum R, Johnson SN (2020) Contrasting effects $\mathrm{f}$ Miocene and Anthropocene levels of atmospheric $\mathrm{CO}_{2}$ on silicon accumulation in a model grass. Biol Lett 16:20200608. https://doi.org/10.1098/rsbl.2020.0608

9. Coughenour MB (1985) Graminoid responses to grazing by large herbivores: adaptations, exaptations, and interacting processes. Ann Mo Bot Gard 72:852-863. https://doi.org/10.1111/13652435.12711

10. Wang M, Gao L, Dong S, Sun Y, Shen Q, Guo S (2017) Role of silicon on plant-pathogen interactions. Front Plant Sci 8:701. https://doi.org/10.3389/fpls.2017.00701

11. Carnelli AL, Madella M, Theurillat JP, Ammann B (2002) Aluminum in the opal silica reticule of phytoliths: a new tool in palaeoecological studies. Am J Bot 89(2):346-351. https://doi. org/10.3732/ajb.89.2.346

12. Kameník J, Mizera J, Řanda Z (2013) Chemical composition of plant silica phytoliths. Environ Chem Lett 11(2):189-195. https:// doi.org/10.1007/s10311-012-0396-9

13. Andriopoulou NC, Christidis GE (2020) Multi-analytical characterization of wheat biominerals: impact of methods of extraction on the mineralogy and chemistry of phytoliths. 
Archaeol Anthropol Sci 12:186. https://doi.org/10.1007/ s12520-020-01091-5

14. Parr J, Sullivan L, Chen B, Ye G, Zheng W (2010) Carbon biosequestration within the phytoliths of economic bamboo species. Glob Change Biol 16(10):2661-2667. https://doi.org/10. 1111/j.1365-2486.2009.02118.x

15. Yang $S$, Hao $Q$, Wang $H$, Van Zwieten $L$, Yu C, Liu T, Yang X, Zhang $X$, Song Z (2020) A review of carbon isotopes of phytoliths: implications for phytolith-occluded carbon sources. J Soils Sedim. https://doi.org/10.1007/s11368-019-02548-4

16. Santos GM, Masion A, Alexandre A (2018) When the carbon being dated is not what you think it is: insights from phytolith carbon research. Quatern Sci Rev 197:162-174. https://doi.org/ 10.1016/j.quascirev.2018.08.007

17. Piperno DR (2006) Phytoliths: A comprehensive guide for archaeologists and paleoecologists. Altamira Press, Lanham

18. Malone M, White P, Morales MA (2002) Mobilization of calcium in glasshouse tomato plants by localized scorching. J Exp Bot 53:83-88. https://doi.org/10.1093/jexbot/53.366.83

19. Karabourniotis G, Horner HT, Bresta P, Nikolopoulos D, Liakopoulos $G$ (2020) New insights into the functions of carbon-calcium inclusions in plants. New Phytol 228(3):845-854. https://doi.org/ 10.1111/nph.16763

20. Cuadra VP, Hermann P (2013) Characterization and macropattern of calcium oxalate phytoliths in Argentinean endemic species of Chenopodioideae (Amaranthaceae). Quatern Int 287:83-88. https://doi.org/10.1016/j.quaint.2011.10.010

21. Pierantoni $M$, Tenne R, Rephael B, Brumfeld V, van Casteren $A$, Kupczik K, Oron D, Addadi L, Weiner S (2018) Mineral deposits in Ficus leaves: morphologies and locations in relation to function. Plant Physiol 176:1751-1763. https://doi.org/10.1104/pp. 17.01516

22. Ragel P, Raddatz N, Leidi EO, Quintero FJ, Pardo JM (2019) Regulation of K+ nutrition in plants. Front Plant Sci 10:281. https:// doi.org/10.3389/fpls.2019.00281

23. Dreyer I, Uozumi N (2011) Potassium channels in plant cells. FEBS J 278(22):4293-4303. https://doi.org/10.1111/j.1742-4658. 2011.08371.x

24. Unadkat K, Parikh P (2019) Localization of Cadmium metal ion in Lemna polyrhiza L. using SEM morphology and EDX analysis. Environ Conserv J 20:81-86. https://doi.org/10.36953/ECJ.2019. 1008.1214

25. Motomura H, Fujii T, Suzuki M (2004) Silica deposition in relation to ageing of leaf tissues in Sasa veitchii (Carriere) Rehder (Poaceae: Bambusoideae). Ann Bot 93(3):235-248. https://doi. org/10.1093/aob/mch034

26. Motomura H, Fujii T, Suzuki M (2006) Silica deposition in abaxial epidermis before the opening of leaf blades of Pleioblastus chino (Poaceae, Bambusoideae). Ann Bot 97(4):513-519. https://doi. org/10.1093/aob/mcl014

27. Gu Y, Liu H, Wang H, Li R, Yu J (2016) Phytoliths as a method of identification for three genera of woody bamboos (Bambusoideae) in tropical southwest China. J Archaeol Sci 68:46-53. https://doi.org/10.1016/j.jas.2015.08.003

28. Chen I, Li KT, Tsang CH (2020) Silicified bulliform cells of Poaceae: morphological characteristics that distinguish subfamilies. Bot Stud 61(1):1-25. https://doi.org/10.1186/s40529-020-0282-x

29. Leandro TD, Rodrigues TM, Clark LG, Scatena VL (2018) Fusoid cells in the grass family Poaceae (Poales): a developmental study reveals homologies and suggests new insights into their functional role in young leaves. Ann Bot 122(5):833-848. https://doi. org/10.1093/aob/mcy025

30. Kalliola R, Linna A, Toiviainen L, Ruokolainen K (2019) Phytolith assemblages in the leaves of Guadua bamboo in Amazonia. J Bamboo Rattan 18(2):31-43

31. de Carvalho AL, Nelson BW, Bianchini MC, Plagnol D, Kuplich TM, Daly DC (2013) Bamboo-dominated forests of the Southwest

SN Applied Sciences
Amazon: detection, spatial extent, life cycle length and flowering waves. PLoS ONE 8:e54852. https://doi.org/10.1371/journal. pone.0054852

32. Van doninck J, Westerholm J, Ruokolainen $\mathrm{K}$, Tuomisto H, Kalliola $R$ (2020) Dating flowering cycles of Amazonian bamboo-dominated forests by supervised Landsat time series segmentation. Int J Appl Earth Observ Geoinf 93:102196. https://doi.org/10. 1016/j.jag.2020.102196

33. Ferreira E, Kalliola R, Ruokolainen K (2020) Bamboo, climate change and forest use: a critical combination for southwestern Amazonian forests? Ambio 49:1353-1363. https://doi.org/10. 1007/s13280-019-01299-3

34. Madella M, Alexandré A, Ball T (2005) International code for phytolith nomenclature 1.0. Ann Bot 96(2):253-260

35. White PJ, Broadley MR (2003) Calcium in plants. Ann Bot 92:487511. https://doi.org/10.3389/fpls.2014.00589

36. Koprivova A, Kopriva S (2014) Molecular mechanisms of regulation of sulfate assimilation: first steps on a long road. Front Plant Sci 5:589. https://doi.org/10.3389/fpls.2014.00589

37. Hawkesford M, Horst W, Kichey T, Lambers H, Schoerring J, Skrumsager I, White P (2012) Functions of macronutrients. In: Marschner $P$ (ed) Marschner's mineral nutrition of higher plants. Academic Press, Boston, pp 135-189. https://doi.org/10.1016/ B978-0-12-384905-2.00006-6

38. Alexandre A, Basile-Doelsch I, Delhaye T, Borshneck D, Mazur JC, Reyerson P, Santos GM (2015) New highlights of phytolith structure and occluded carbon location: 3-D X-ray microscopy and NanoSIMS results. Biogeosciences 12(3):863-873. https:// doi.org/10.5194/bg-12-863-2015

39. Dabney C III, Ostergaard J, Watkins E, Chen C (2016) A novel method to characterize silica bodies in grasses. Plant Methods 12(3):1-10. https://doi.org/10.1186/s13007-016-0108-8

40. Raven JA (2001) Silicon transport at the cell and tissue level. In: Datnoff LE, Snyder GH, Korndorfer GH, eds. Silicon in agriculture. Amsterdam, The Netherlands: Elsevier Science, pp 41-55. https://doi.org/10.1016/S0928-3420(01)80007-0

41. Kaur H, Greger M (2019) A review on Si uptake and transport system. Plants 8(4):81. https://doi.org/10.3390/plants8040081

42. Exley C, Guerriro G, Lopez X (2020) How is silicic acid transported in plants? SILICON 12:2641-2645. https://doi.org/10.1007/ s12633-019-00360-w

43. Matschi S, Vasquez MF, Bourgault R, Steinbach $P$, Chamness J, Kaczmar N, Gore MA, Molina I, Smith LG (2020) Structure-function analysis of the maize bulliform cell cuticle and its potential role in dehydration and leaf rolling. Plant Direct 00:1-21. https:// doi.org/10.1002/pld3.282

44. Zhang JJ, Wu SY, Jiang L, Wang JL, Zhang X, Guo XP, Guo CY, Wan JM (2015) A detailed analysis of the leaf rolling mutant sll2 reveals complex nature in regulation of bulliform cell development in rice (Oryza sativa L.). Plant Biol 17(2):437-448. https:// doi.org/10.1111/plb.12255

45. Vega AS, Castro MA, Guerreiro C (2016) Ontogeny of fusoid cells in Guadua species (Poaceae, Bambusoideae, Bambuseae): evidence for transdifferentiation and possible functions. FloraMorphol Distrib Funct Ecol Plants 222:13-19. https://doi.org/10. 1016/j.flora.2016.03.007

46. Fadrique B, Gann D, Saatchi NBW, S, Feeley KJ, (2021) Bamboo phenology and life cycle drive seasonal and long-term functioning of Amazonian bamboo-dominated forests. J Ecol 109(2):860-875. https://doi.org/10.1111/1365-2745.13512

Publisher's Note Springer Nature remains neutral with regard to jurisdictional claims in published maps and institutional affiliations. 